\title{
From isolation to connectivity: the effect of floodplain lake restoration on sediments as habitats for macroinvertebrate communities
}

\author{
Krystian Obolewski $^{1}$ (1) $\cdot$ Katarzyna Glińska-Lewczuk ${ }^{2} \cdot$ Martyna Bąkowska $^{1}$
}

Received: 13 January 2017 / Accepted: 14 November 2017 / Published online: 21 November 2017

(c) The Author(s) 2017. This article is an open access publication

\begin{abstract}
The present study aimed to identify potential macrozoobenthic habitat indicators of the ecological success of restoration projects. As a part of the complex restoration project in the Słupia River floodplain (N Poland), the connectivity between three oxbow lakes and the river channel was re-established to improve biodiversity of the floodplain area, including bottom fauna. Following restoration, changes in the dynamics of flowing water and water levels induced the transformation of oxbows from plesiopotamal (lentic) to eupotamal (lotic) and subsequently to parapotamal (semi-lotic) habitats. The restored sites underwent a rapid depletion of benthic coarse particulate organic matter, with direct changes in most of the investigated parameters of bottom sediments, including conductivity, total organic carbon, soluble reactive phosphorus and total nitrogen. Redundancy analysis revealed that the changes in benthic fauna structure resulted from the increased connectivity with the river (flow rate) and changes in the chemical properties of sediments. The restored oxbow lakes were colonized by six new macroinvertebrate species whose density increased substantially. The assessment of the overall river-floodplain system restoration project indicated positive implications for improving the qualitative and quantitative structure of benthic fauna. However, to confirm ecologically successful restoration, it is necessary to evaluate appropriate sets of indicators based on a complex food web structure and more efficient or enhanced ecosystem functions. This study contributes to the discussion of sustainable management of floodplains to provide benefits to macroinvertebrates as indicators of aquatic ecosystem health under different restoration activities.
\end{abstract}

Keywords Benthic invertebrates $\cdot$ Floodplain $\cdot$ Bottom sediments $\cdot$ Restoration

\section{Introduction}

The habitat heterogeneity of aquatic ecosystems has been recognized as an important factor promoting biological diversity, particularly that of invertebrate (Schiemer et al.

Krystian Obolewski

obolewsk@ukw.edu.pl

Katarzyna Glińska-Lewczuk

kaga@uwm.edu.pl

Martyna Bąkowska

bakowska.martyna@ukw.edu.pl

1 Department of Hydrobiology, Faculty of Natural Sciences, University of Kazimierz Wielki in Bydgoszcz, Bydgoszcz, Poland

2 Department of Water Resources, Climatology and Environmental Management, Faculty of Environmental Management and Agriculture, University of Warmia and Mazury in Olsztyn, Olsztyn, Poland
1999; Buijse et al. 2005) and fish communities (Miranda et al. 2014; Dolédec et al. 2015). Areas with the highest biodiversity potential include floodplain river ecosystems. Under natural conditions, floodplains comprise a mosaic of habitats subjected to a continuum of hydrological conditions in which side arms, oxbow lakes, and paleomeanders, which represent habitats of various degrees of connectivity, are arrayed along both sides of the river bed, providing 'hot-spots' of biodiversity (Ward et al. 2002). These habitats serve as flow channels, particularly during periods of high water, and offer reproduction sites for aquatic, amphibian and terrestrial organisms (Reckendorfer 2004).

The tendency of meandering rivers to create bends due to erosion and accumulation processes is part of the natural transformation of river channels. However, accumulating evidence indicates that many floodplains in Europe and North America have been disrupted due to straightening and embankment of river channels. Past practices have resulted in the disconnection of floodplains from rivers, with a loss 
in biodiversity and a demand for complex restoration work. These hydrotechnical projects have led to permanent isolation of former meander bends, consequently disrupting natural processes of water exchange between cut-offs and the river channel. High and rare flood events appear to be crucial to generate floodplain habitat diversity (Amoros and Bornette 2002) and to allow organisms to exploit stagnant waters as a result of adaptive strategies. A key factor linking river-floodplain system (RFS) properties and the structure of floodplain biota is hydrologic variability, as described by the "flood pulse concept" (Junk et al. 1989). The degree of connectivity of floodplain water bodies is mirrored by the substrate conditions: highly organic mud is typical of stagnant isolated water bodies, whereas lotic water bodies feature coarse, highly permeable mineral deposits.

Regardless of the cause, a lack of habitat regeneration by fluvial dynamics leads to the disappearance of lentic ecosystems. Cut-offs quickly become filled with sediments as a result of autogenic processes and/or allogenic processes, i.e., accumulation of the material carried by the river during inundation events and by ground water (Sieczko and Peduzzi 2014). Soon after, the isolated water bodies undergo eutrophication and then terrestrialization (Obolewski et al. 2016; Palmer et al. 2005). The lakes accumulate organic matter and become shallower, with decreasing biodiversity due to progressive domination of species tolerant of the changes in environmental quality (e.g., Obolewski 2011; Paillex et al. 2015).

The properties of the bottom substratum determine the abundance and diversity of benthic macroinvertebrates (Culp et al. 1983; Rempel et al. 2000; Obolewski and GlińskaLewczuk 2013). However, macrozoobenthos influence bottom sediments (Jones and Jago 1992; Żbikowski and Kobak 2007) and improve water exchange by increasing oxygen levels above the sediment (Svensson and Leonardson 1996). The rate and direction of matter exchange between water and bottom sediments are also influenced by the abundance and taxonomic composition of zoobenthos (Covich et al. 1999). Restoration tasks within a single RFS that rely mainly on the reconnection of aquatic ecosystems with the river channel influence habitat diversity measured on the scale of a single sampling site ( $\alpha$-diversity), ecosystem ( $\beta$ - diversity) or floodplain ( $\gamma$-diversity).

Floodplain lake restoration refers mainly to changes in the pathways of water, resources and organisms between water bodies. How the interaction between water flow intensity and direction influences the turnover of macroinvertebrates in floodplain systems remains unclear, as does the magnitude, pathway, and distance through which the floodwater transports the biota, particularly macroinvertebrates, to newly inundated habitats in a lateral connectivity gradient (Mesa et al. 2012).
Our previous studies (Obolewski and Glińska-Lewczuk 2013; Obolewski et al. 2016) demonstrated that the restoration effects in RFSs can be analyzed at different temporal scales. Short-term effects are observed soon after reconnection when the system is not stable and the structures of the sediment, water quality, and biota (here: macrozoobenthos) vary significantly between seasons, whereas long-term effects, usually on a multi-year scale, may be assessed when the biota attains relative multiseasonal stability.

Distinct spatial gradients in sediment structure are destroyed within a single floodplain lake during flushing with river water. Activation of water leads to the resuspension of bottom sediments and the release of accumulated nutrients into the water. This sudden change in habitat conditions is a source of stress for hydrobionts, particularly highly sensitive benthic macroinvertebrates. We have demonstrated (Obolewski and Glińska-Lewczuk 2013; Obolewski et al. 2016) that water flowing into floodplain lakes carries suspended matter that is deposited at the bottom, contributing to lake shallowing and inhibiting connectivity in the RFS.

In the current study, we observed changes in floodplain lakes at 3 and 5 years after restoration, and these observations were used to test the following hypotheses: (1) the chemical composition of bottom sediments in floodplain lakes is modified in response to reconnection with the river channel; (2) the observed changes subside gradually as the flow between the floodplain lake and the river is restricted to create a semi-lotic system; (3) the density and species richness of macroinvertebrates are largely determined by the physicochemical properties of bottom sediments; (4) oneside connectivity of floodplain lakes with the river channel plays a key role in restoration processes by creating a distinct gradient in sediment structure along a floodplain lake to support microhabitat heterogeneity for various groups of macroinvertebrates. Full hydrological connectivity (both arms) of the RFS plays a less important role.

\section{Materials and methods}

\section{Study sites}

The surveyed area occupies the central part of the Słupia River floodplain, which features numerous water bodies

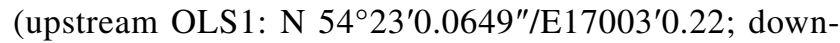
stream OLS 3: $\left.\mathrm{N}^{\circ} 4^{\circ} 23^{\prime} 0.2811^{\prime \prime} / \mathrm{E} 17^{\circ} 02^{\prime} 0.0166^{\prime \prime}\right)$. The river is one of the largest watercourses feeding the southern Baltic Sea (catchment area- $1620 \mathrm{~km}^{2}$, length $-138.6 \mathrm{~km}$, mean annual flow rate $-15.5 \mathrm{~m}^{3} \mathrm{~s}^{-1}$; flows exceeding $100 \mathrm{~m}^{3} \mathrm{~s}^{-1}$ are generally noted between October and March) (Obolewski 2011). The Stupia River floodplain is $0.3-0.4 \mathrm{~km}$ wide. Its meandering section spreads out over $19 \mathrm{~km}$ between the village of Lubun and the town of Słupsk (N Poland). The 
floodplain area is covered mostly by meadows and pastures, which are used for agricultural purposes, and $15.6 \%$ of its area is occupied by wetland ecosystems. In the early twentieth century, the river channel was artificially regulated, and its meanders were cut off, which led to the formation of nearly 50 oxbow lakes in the floodplain on both sides of the main stream along a $20-\mathrm{km}$ section.

In the summer of 2008, water flow was restored in three floodplain lakes by dredging, and two of those water bodies were merged (Fig. 1). Two cut-off (oxbow) lakes (OLS1 and OLS2) and one parapotamal lake (OLS3) were selected for the restoration project. All three water bodies were smaller than 1 hectare, and their maximum depth did not exceed $1.5 \mathrm{~m}$. Between 2008 and 2011, the analyzed lakes constituted lotic water bodies, but in 2012, the upstream arm began to fill with suspended matter, and the lakes were gradually transformed into semi-lotic water bodies (Obolewski et al. 2016).

The first series of samples was collected before hydrotechnical work started in the summer of 2007. After the disruptive effects of the restoration measures had subsided, the second series of samples was collected in the summer of 2011. The third batch was sampled in the summer of 2013 soon after water flow in the upstream arm of the river became blocked. The above approach supported a comparison of changes resulting from the loss of connectivity in the RFS. Samples of benthic sediments and benthic macroinvertebrates were collected four times in each year of the study, in April, June, August and October. Sampling took place in the upstream and downstream arms and in the center of floodplain lakes (each $\mathrm{N}=72$ ) as well as in a reference point in the river $(\mathrm{N}=12)$. The merged lakes OLS1 and OLS2 were regarded as a single body of water.

\section{Hydrological analyses}

River gauge levels and discharges were measured in Słupsk (33.5 km from the river mouth). Discharge (Q) was calculated as the product of the cross-section of the channel or basin of the oxbow lake and average flow velocity in the cross-sectional area. Flow velocity in oxbows was measured weekly during the study period using an electromagnetic

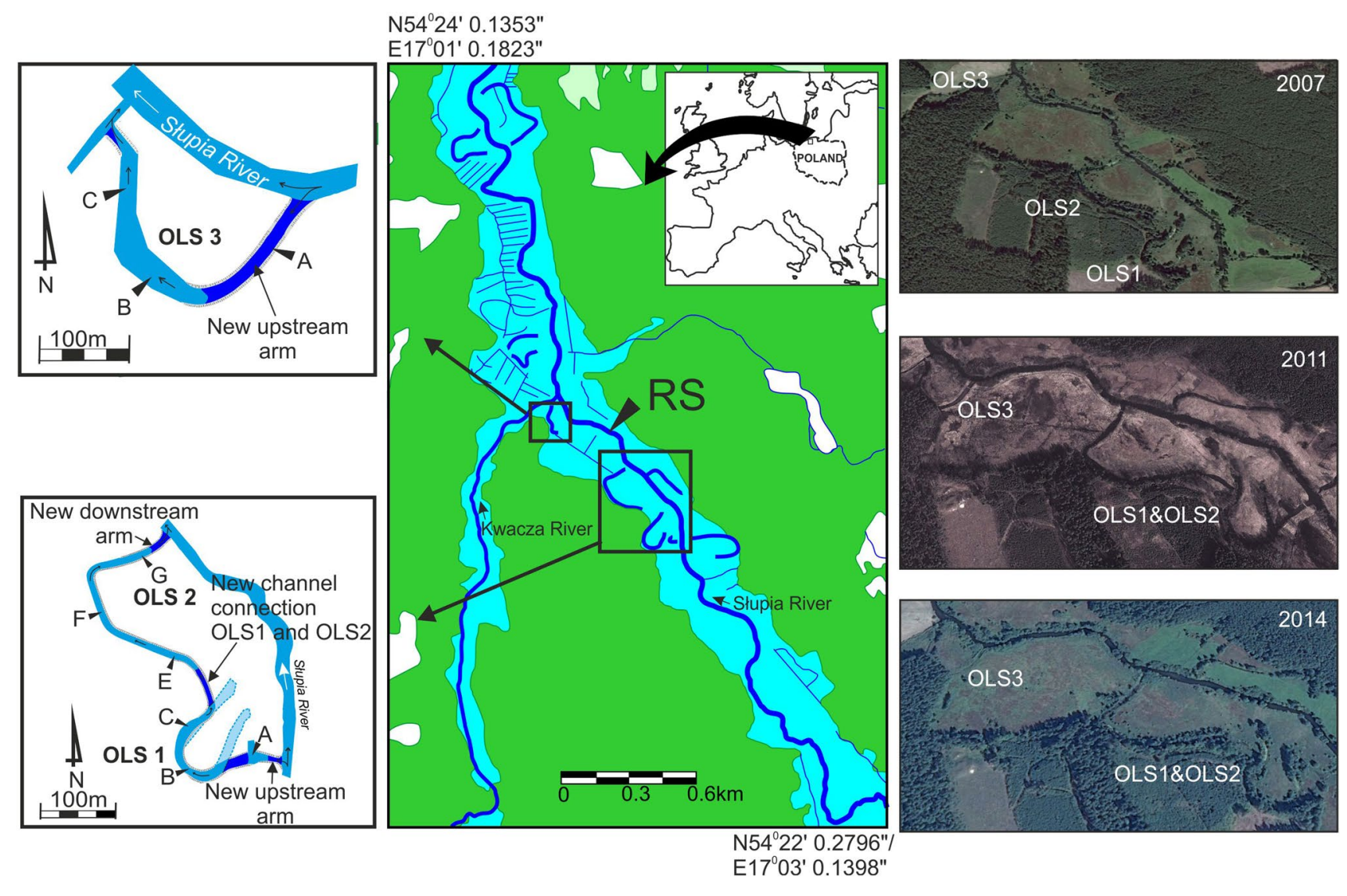

Fig. 1 Location of study area and changes of restored floodplain lakes in 2007 (1 year before restoration) and in 2011 and 2014 (3 and 6 years after restoration) 
flow meter (model 801-flat type; Valeport, UK). Gauge levels were recorded every hour using three automatic data loggers (Mini-Diver, Van Essen Instruments, Holland) positioned in each analyzed water body. Gauge levels were compensated by changes in atmospheric pressure with a BaroDiver data logger (Van Essen Instruments, Holland).

\section{Physicochemical analyses}

Physicochemical variables of sediments were selected for relation with the hydrological connectivity of the floodplain lakes. Nine sediment samples were captured using an Ekman type dredge (Eijkelkamp, Holland) from the upstream, downstream and deepest sites in each of the three restored oxbow lakes. To evaluate the grain size as well as physical and chemical sediment composition, the samples were taken from the surface layer (ca. $0-20 \mathrm{~cm}$ ).

Bulk density (BD) was calculated as dry mass by volume $\left(\mathrm{g} \mathrm{cm}^{-3}\right)$, and organic matter $(\mathrm{OM})$ was estimated by loss on ignition (LOI) in a muffle furnace $\left(450{ }^{\circ} \mathrm{C}\right.$ for $6 \mathrm{~h}$ ) and expressed as a percentage of sediment dry mass (DM). Particle size distribution was measured aerometrically by Casagrande's method as modified by Prószyński to assess the proportions of clay $(<2 \mu \mathrm{m})$, silt $(2-63 \mu \mathrm{m})$ and sand $(>63 \mu \mathrm{m})$. Reaction $\mathrm{pH}$ was measured potentiometrically both in $\mathrm{KCl}$ and $\mathrm{H}_{2} \mathrm{O}$, and conductivity (EC) was measured using an HQ40D (HACH, USA). Calcium carbonate was determined with the gasometric method using Scheibler's device following digestion of sediment in $\mathrm{H}_{2} \mathrm{SO}_{4}$ and $\mathrm{H}_{2} \mathrm{O}_{2}$ in an MLS-1200 MEGA microwave digestion unit (method according to HACH, Loveland, Colorado, USA). Phosphorus was photometrically measured as soluble reactive phosphorus (SRP) using the molybdenum blue method. This method employs a single-color reagent consisting of an acidified solution of ammonium molybdate, ascorbic acid and antimony-tartrate. The blue phosphomolybdenum complex formed is read colorimetrically through a $50 \mathrm{~mm}$ pathlength flowcell at $880 \mathrm{~nm}$ (Murphy and Riley 1962). The specific automated method used is described in Technicon (1973) with the following modifications. Nitrogen (TN) was measured as ammonium $\mathrm{NH}_{4}-\mathrm{N}$ after Nessler reaction at $425 \mathrm{~nm}$ $(\mathrm{HACH})$. Magnesium $(\mathrm{Mg})$, potassium $(\mathrm{K})$ and sodium $(\mathrm{Na})$ were analyzed using a PerkinElmer (AAnalyst 200) atomic absorption spectrophotometer. Total organic carbon (TOC) was measured with a TOC-analyzer 5000A (Shimadzu, Japan). Each measurement was performed in triplicate.

\section{Fauna collection}

Analyses of aquatic invertebrates were limited to benthic invertebrates. Three subsamples were collected with an Ekman grab (sample area: $225 \mathrm{~cm}^{2}$ ) at the sampling sites of the bottom sediments. Sampling of benthic fauna was performed simultaneously with sediment sampling. Samples were rinsed in a sieve with a $0.5-\mathrm{mm}$ mesh size and fixed in $4 \%$ formaldehyde solution. In the laboratory, invertebrates were separated from sediments and identified to genus or species level, excluding Oligochaeta (phylum level). The results were expressed in terms of $1 \mathrm{~m}^{2}$ of lake bottom area. The identified species were classified to the functional feeding group (FFG) according to the classification proposed by Merritt and Cummins (2007) and Willacker et al. (2009):

1. Shredders (Sd)-Crustacea (Gammarus pulex L., Asellus aquaticus L.), Gastropoda (Viviparus contectus Millet);

2. Gatheringcollectors (GC)—Diptera larvae (Chironomus sp., Sergentia sp.), Oligochaeta;

3. Grazer scrapers (GS) -Ephemeroptera larvae (Cloëon dipterum L., Ephemera danica Müller), Diptera larvae (Polypedilum sordens Wulp.);

4. Predators (Pd)-Hirudinea (Erpobdella octoculata L., Glossiphonia complanata L., Helobdella sp.), Megaloptera (Sialis fuliginosa L.), Odonata larvae (Libellula quadrimaculata Feb., Lestes sp.), Coleoptera (Dytiscus marginalis L., Cymbiodyta sp.), Heteroptera (Nepa cinerea L., Corixa sp., Heterocorixa sp., Sigara sp.), Diptera larvae (Procladius sp., Chaoborus sp.);

5. Filtering collectors (FC)-Bivalvia (Anodonta anatina L., Pisidium sp., Sphaerium sp.);

The results were used to calculate $\mathrm{D} \alpha$ Shannon's diversity index $\left(\mathrm{H}^{\prime}\right)$, Pielou's evenness index $\left(\mathrm{J}^{\prime}\right)$ and $\mathrm{D}_{\beta}$ (Whittaker index) in the Past v. 3.01 program. Gamma-diversity was calculated using the formula: $\mathrm{D} \gamma=\mathrm{D} \alpha \times \mathrm{D} \beta$.

\section{Data analysis}

For statistical analysis, floodplain lakes were classified based on the degree of connectivity with the river according to the typology proposed by Amoros and Roux (1988). The final dataset contained basic environmental variables: year of analysis combined with the degree of connectivity phase between an oxbow lake and the river $(1-$ plesiopotamal phase, 2-eupotamal; 3-parapotamal), water flow, physicochemical parameters of bottom sediments, and abundance of benthic macroinvertebrates.

To evaluate general differences in macrozoobenthos structure, we analyzed water bodies (OLS1\&2, OLS3) in the studied years and performed analysis of variance (ANOVA) with the Kruskal-Wallis test $(K-W)$ followed by Dunn's test in GraphPad Prism 5.01 (GraphPad Software, USA). The following variables were determined: discharges, physicochemical parameters of bottom sediments, mean density of invertebrates, species richness of invertebrates, D $\alpha$ diversity Shannon's index $\left(\mathrm{H}^{\prime}\right)$ and Pielou's evenness index $\left(\mathrm{J}^{\prime}\right)$. 
We obtained groupings of species and plots based on benthic fauna community composition using two-way hierarchical agglomerative cluster analyses in PC-ORD 6.08 (McCune and Mefford 2011). We performed two-way cluster analysis independent of group samples and species and then combined these analyses into a single diagram to permit observation of the associations between groups of sample units and species. The data were relativized by species maximum to diminish but not eliminate the influence of species totals on species clustering. We used Ward's method as the linkage method on Euclidean distances.

The dataset was $\log (\mathrm{x}+1)$ transformed (ter Braak and Smilauer 2002), and the results were checked for normal distribution (Shapiro-Wilk test) and homoscedasticity (Leven's test). Principal component analysis (PCA) was performed using the covariance method to determine the relative significance of environmental factors in explaining the variability of the tested samples. The redundancy between environmental predictors was determined by redundancy analysis (RDA) considering the variance inflation factor (VIF). Independent variables with VIF $>10$ were eliminated from further analyses because they supplied redundant information. The length of the gradient on the F1 axis was determined by detrended correspondence analysis (DCA). The results were non-monotonic when the standard deviation for the analyzed variables was greater than 2 (ter Braak 1995). Consequently, the relationships between environmental parameters (year of analysis, site, discharge, physicochemical properties of sediments) and density of benthic fauna were analyzed by RDA (ter Braak 1995). The statistical significance of canonical axes was determined in the Monte Carlo permutation test (Legendre and Legendre 2012). A subset of independent variables representing the relationships between environmental factors and the species/taxa of benthic fauna was identified by eliminating factors that were not significant for the model. Data were processed statistically in Canoco 4.5 software at probability levels of $* p<0.05$ and $* * p<0.01$.

The General Linear Model (GLM) was used to detect differences in feeding groups of benthic organism abundances and $\alpha$-diversity in consecutive periods of lake monitoring and in the selected RDA-significant environmental variables. We used a Poisson error distribution to construct the model and checked for over dispersion of the data (Crawley 2007). The procedure was performed using Past v.3.01c software.

\section{Results}

\section{Hydrological conditions}

In 2011 and 2014, gauge levels in the Słupia River ranged from 13.20 to $14.21 \mathrm{~m}$ above sea level (a.s.l.), and average discharge $\left(\mathrm{Q}_{\mathrm{AV}}\right)$ was estimated as $14 \mathrm{~m}^{3} \mathrm{~s}^{-1}$. Inundation did
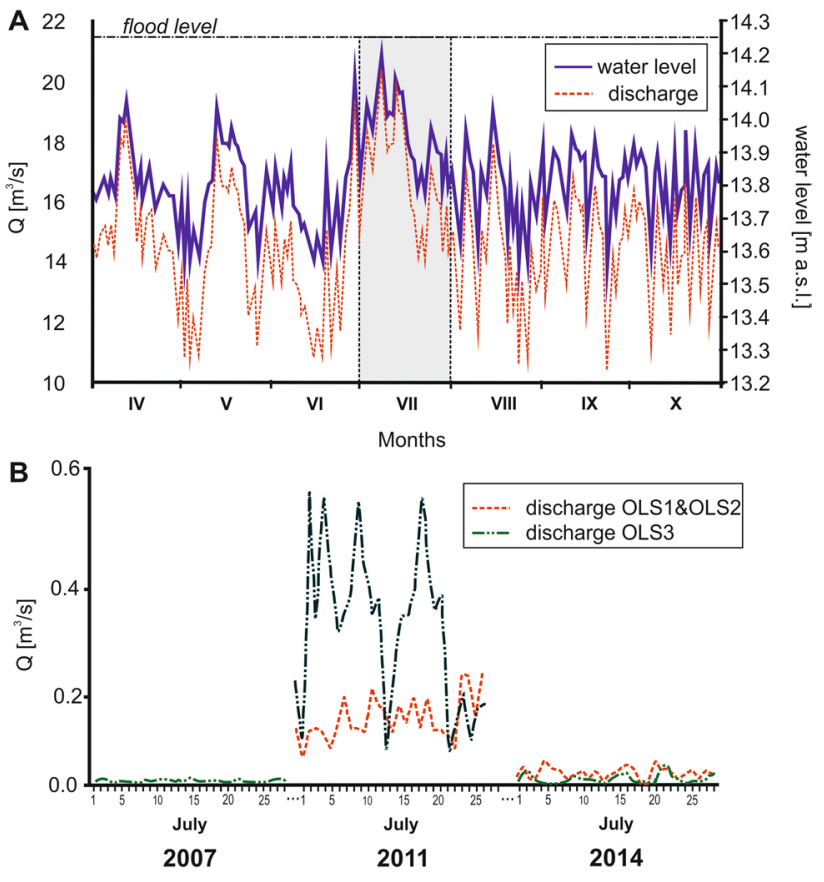

Fig. 2 a Hydrograph of average daily water levels and flows of the Słupia River at a gauge in Słupsk in the period between April and October 2007-2014. b Hydrograph of water flow in the studied floodplain lakes in the period of study

not occur in the analyzed period. In the Słupia River floodplain, inundation occurs when water levels exceed $14.25 \mathrm{~m}$ a.s.l and when the river flow exceeds $22 \mathrm{~m}^{3} \mathrm{~s}^{-1}$ (Fig. 2a). The highest water levels in the studied site were noted in July 2007 due to heavy rainfall. The lowest water levels were observed in early fall (October). The floodplain lakes are directly connected to the main river channel; therefore, variations in lake levels and discharges are affected by the river. At the beginning of the study (July 2007), the lakes OLS1 and OLS 2 did not maintain surface connectivity with the river, whereas OLS3 was slightly connected to the river by its downstream $\operatorname{arm}\left(\mathrm{Q}_{\mathrm{av}}=0.06 \mathrm{~m}^{3} \mathrm{~s}^{-1}\right)$. Consequently, all oxbow lakes were treated as plesiopotamal water bodies. The floodplain lakes became eupotamal habitats in July 2011 due to hydrotechnical work but were transformed into parapotamal water bodies by July 2014 (Fig. 2B). In 2011, significantly higher discharges were noted in OLS3 than in OLS1\&2 $\left(K-W=14.78^{*}\right)$, whereas in 2014 , water flows were similar in all floodplain lakes.

\section{Physicochemical properties of bottom sediments}

In this study, samples were collected from relatively new sediment layers that had formed after the restoration. Variations in the physical parameters of the analyzed sediments 


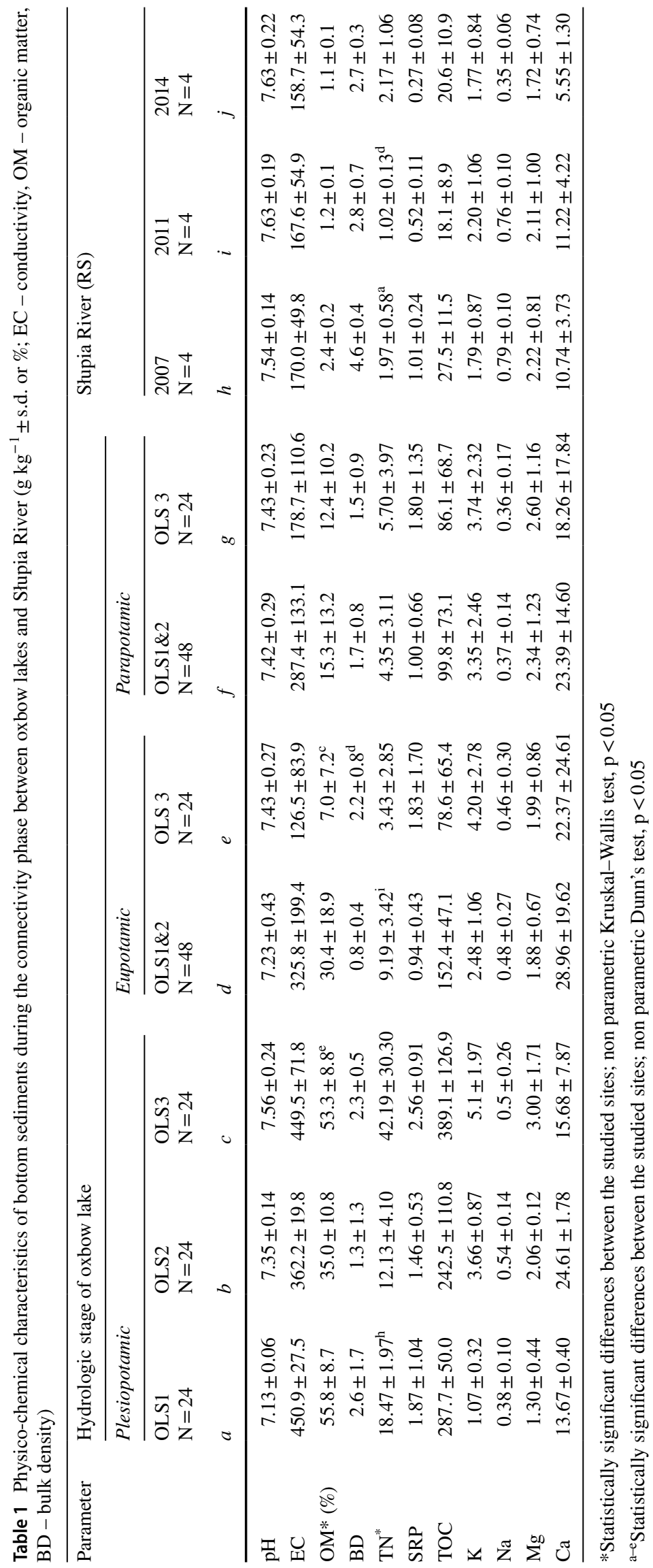


were noted between 2007 and 2014. Statistically significant differences were observed only in bulk density (BD) between OLS2 and the river in $2007\left(K-W=16.17^{*}\right.$, Table 1).

Plesiopotamal water bodies, i.e., lakes isolated from the river, had the highest particulate organic matter (POM) content. After reconnection with the river, the content of POM decreased visibly when floodplain lakes were flushed with river water (2011). When full connectivity in the RFS was lost again (2014), lentic conditions favored the accumulation of organic debris, which resulted in a doubling of the content of organic matter in lake sediments and relatively high values of TOC (86-152 mg kg-1 DM), TN (5.7-9.2 $\left.\mathrm{mg} \mathrm{kg}^{-1} \mathrm{DM}\right)$ and mineralization as expressed by EC $\left(179-326 \mu \mathrm{S} \mathrm{cm}^{-1}\right)$.

A nearly twofold increase was observed in the values of $\mathrm{TN}$ in the parapotamal phase; however, significant changes in TN in the sediment occurred in OLS1, both during the independent and connection to OLS2 phases. Total nitrogen concentrations were significantly higher in plesiopotamal phase OLS1 than in the river $\left(K-W=38.67^{* *}\right)$ and parapotamal OLS1\&2 than in the river in the eupotamal phase $\left(K-W=13.67^{*}\right.$, Table 1$)$. The higher water residence time contributed to greater sedimentation and deposition of phosphorus.

\section{Taxonomic richness and abundances}

A total of 1481 individuals representing 25 taxonomic groups were sampled from the restored oxbow lakes and Stupia River in both years of the different hydrological connectivity phases. Significant differences in the taxonomic composition of invertebrates were noted between the different phases of connection of the RFS. In the plesiopotamal phase, 19 taxa were identified, but in the eupotamal phase, only 5 taxa were identified. Parapotamal-phase benthic fauna were represented by 18 taxa (Table 2). After restoration (eupotamal phase), the number of taxa in the connected lakes OLS1\&2 decreased, particularly compared with OLS2 in plesiopotamal water bodies $\left(K-W=14.00^{*}\right)$. The greatest increase was observed in OLS3 $\left(K-W=17.44^{* *}\right.$, Table 2$)$.

The density of benthic macroinvertebrates increased significantly $\left(K-W=15.31^{* *}\right)$ between the plesiopotamal phase and after restoration of the eupotamal and parapotamal phases as a result of the project. Invertebrate density increased 27-fold in OLS1\&2 and 26-fold in OLS3, and the noted increase was statistically significant (Dunn's test*) in both cases. In the plesiopotamal phase, invertebrate abundance was very high, but 3 years after restoration, invertebrate abundance was low and stable in both OLS1\&2 and OLS3. There were no statistically significant differences in the values of the index $\mathrm{J}^{\prime}, \mathrm{D}_{\beta}$ and $\mathrm{D}_{\gamma}$ between the studied phases. However, $\mathrm{J}^{\prime}$ and $\mathrm{D}_{\beta}$ were highest in the eupotamal phase, and $\mathrm{D} \gamma$ was highest in the plesiopotamal phase (Table 2).

Significant differences in $\mathrm{D} \alpha$ values $(K-W=16.28 * *)$ were observed between OLS1\&2 and the Stupia River in the eupotamal phase during full RFS connectivity (Dunn's test*). In OLS3, D $\alpha$ values increased nearly twofold after restoration. The values of Pielou's evenness index $\left(\mathrm{J}^{\prime}\right)$ were significantly higher $\left(K-W=11.25^{*}\right.$, Table 3$)$ in the river than in OLS1\&2 (Dunn's test*) in the eupotamal phase. Significant differences in the values of $\mathrm{J}^{\prime}$ were not observed between eupotamal oxbow lakes or between OLS3 and the river.

In the plesiopotamal stage of the RFS, the density of invertebrates in the oxbow lakes was determined by similar numbers of Crustacea, Diptera and a slightly smaller number of Oligochaeta (Fig. 3a). A similar pattern was observed in the eupotamal phase but with more than 30 -fold lower numbers of whole invertebrate groups. In the parapotamal stage, Oligochaeta were most abundant (Fig. 3b). Changes in the level of connectivity within RFS destructively affected the abundance of Crustacea but had a positive effect on Oligochaeta. In the successive hydrological stages of the RFS, among the trophic guilds, the percentage of shredders
Table 2 Mean diversity $( \pm$ SD) of invertebrates inhabiting the oxbow lakes during the connectivity phases (each $\mathrm{N}=72$ )

\begin{tabular}{|c|c|c|c|c|c|c|}
\hline & \multicolumn{2}{|c|}{ Plesiopotamic } & \multicolumn{2}{|c|}{ Eupotamic } & \multicolumn{2}{|c|}{ Parapotamic } \\
\hline & Mean & SD & Mean & SD & Mean & SD \\
\hline No of taxa* & 19 & - & 5 & - & 17 & - \\
\hline Average abundance & 2780.2 & 659.4 & 80.6 & 34.0 & 2367.1 & 1031.0 \\
\hline $\mathrm{D}_{\alpha}^{*}$ & 3.232 & 0.303 & 1.815 & 0.286 & 2.231 & 0.690 \\
\hline $\mathrm{J}^{\prime}$ & 0.308 & 0.251 & 0.614 & 0.412 & 0.160 & 0.316 \\
\hline $\mathrm{D}_{\beta}$ & 0.171 & - & 0.200 & - & 0.172 & - \\
\hline $\mathrm{D}_{\gamma}$ & 0.553 & - & 0.363 & - & 0.384 & - \\
\hline
\end{tabular}

Abundance (indiv. $\mathrm{m}^{-2}$ ), $\mathrm{D}_{\alpha}=$ Shannon diversity index, $\mathrm{J}^{\prime}=$ Pielou's evenness index, $\mathrm{D}_{\beta}$ and $\mathrm{D}_{\gamma}=$ Whittaker diversity index

*Statistically significant differences between the studied sites; non parametric Kruskal-Wallis test, $\mathrm{p}<0.05$ 


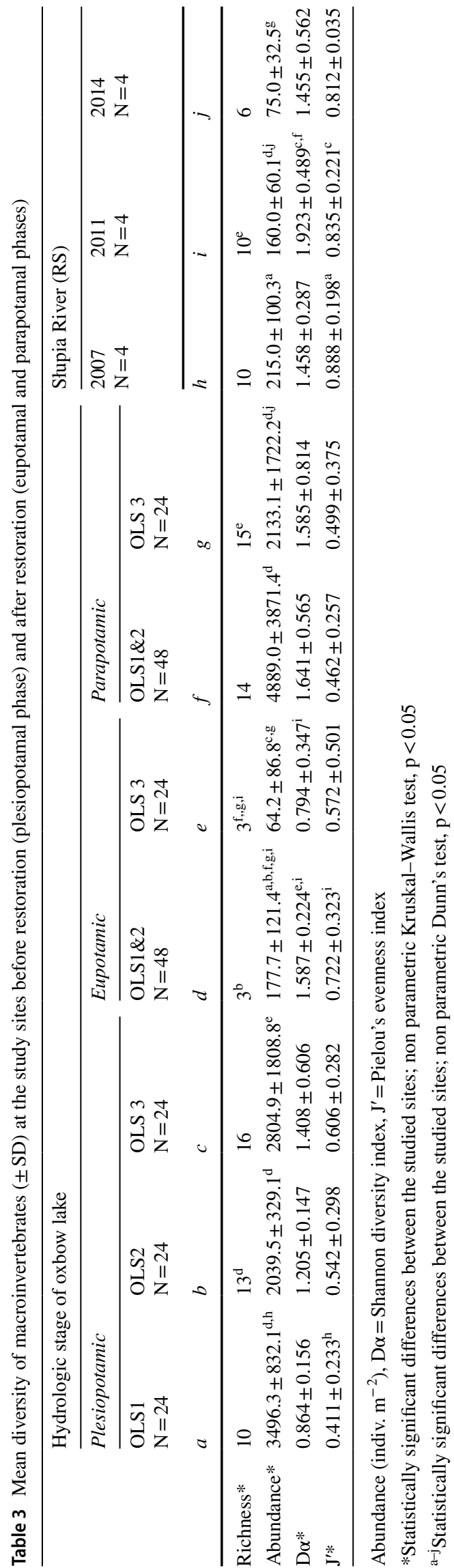

decreased and was substituted by gathering collectors (GC). Predators $(\mathrm{Pd})$ were the least responsive guild with respect to changing hydrological conditions (Fig. 3c). In the absence of plesiopotamal-phase or partial parapotamal-phase connectivity between the oxbows and the river, $\mathrm{GC}$ and filtering collectors (FC) constituted a significant percentage of the fauna.

The cluster analysis revealed two significantly different $(p<0.05)$ groups, referred to as parapotamal- and plesiopotamal-phase groups (Fig. 4). The plesiopotamal water bodies group was represented mostly by Oligochaeta, $E$. octoculata and, to a lesser extent, $V$. contectus, A. aquaticus and larvae of the genus Chironomus in floodplain lakes and by A. anatina, P. amnicum and E. danica in the river. All taxa in the eupotamal-phase group were positively correlated $(r=0.51-0.77, p<0.02)$. The parapotamal floodplain lakes group comprised mainly $S$. fuliginosa, Lestes $\mathrm{sp}$., $N$. cinerea, $P$. sordens, $C$. dipterum and, to a lesser extent, Heteroptera, P. amnicum, Chironomus sp. and Chaoborus sp. All species in this group were positively correlated $(r=0.46-0.56$, $p \leq 0.05$ ). The remaining species were characterized by lower abundances. The eupotamal-phase group invertebrates were positively correlated with OLS3, whereas the parapotamal-phase group taxa did not exhibit such preferences. The qualitative and quantitative structures of the benthic fauna remained fairly stable despite considerable changes in the restored floodplain lakes (Fig. 4).

\section{Influence of environmental factors on macroinvertebrate communities}

In RDA, the first axis (F1) explained $22.7 \%$ and the second axis (F2) explained $19.3 \%$ of the variation. In the group of 15 environmental variables tested in RDA, only 5 (flow, TN, SRP, EC and TOC) significantly influenced the quality of the model (Fig. 5a). Preliminary variable selection produced a high correlation between environmental variables and benthic macroinvertebrates $(r=0.943)$.

The high values of chemical parameters of sediments were correlated with the plesiopotamal phase and directly proportional to the parapotamal phase. The flow itself was strongly associated with the eupotamal phase. In the RDA analysis, the dispersal of benthic fauna was small, with the exception of Oligochaeta and A. aquaticus. The snail $V$. contectus and Heteroptera Sigara sp. were characteristic of the parapotamal period; no such characteristic species were identified in other phases of hydrological connectivity (Fig. 5a).

RDA analysis was also performed for the five functional feeding group (Fig. 5b). The first axis (F1) explained 38.4\% and the second axis (F2) explained $21.9 \%$ of the variation. The same environmental variables were chosen as optimal for the maximum accuracy of the model. High values of SRP 
were conducive to higher abundances of GS, whereas an increase in the concentration of TN determined the density of organisms with various modes of obtaining food. With increased concentrations of TOC, the numbers of shredders $(\mathrm{Sd})$ increased.

The generalized linear model (GLM) showed that the increases in the concentrations of TN, SRP and TOC determined the high values of $\alpha$-diversity ( $\mathrm{H}^{\prime}$ index). Simultaneously, the increase in the flow of water through the RFS limited the diversity of benthic fauna in its various parts.

\section{Discussion}

\section{Effects of restoration on surface-sediment connectivity}

The restoration of hydrological connectivity in the Słupia RFS affected the biotope and parameters of bottom sediments. Those changes were most visible immediately after unblocking of the arm linking the river channel with the floodplain lake. The oxbows were flushed with river water, and fine-grained organic and mineral sediments that had been deposited during the period of isolation from the river were removed.

Significant changes in sediment properties were observed upon the restoration of connectivity (eupotamal phase), and these changes were probably related to the increase in the water content of sediments immediately after reconnection and the increase in the content of POM, TOC and TN (Table 1). The relatively low values of the TOC:TN ratio $(<15)$ in the bottom sediments of oxbow lakes immediately after restoration indicate that phytoplankton were the main source of organic matter (Meyers 2003). The tendency of upstream arms to undergo sedimentation (parapotamal phase) suggests that floodplain lakes naturally evolve into parapotamal habitats when water exchange is inhibited. Those processes contribute to the creation of diverse habitats that accommodate various groups (guilds) of aquatic organisms and enhance biodiversity (Gallardo et al. 2014; Sartori et al. 2015). Changes in the spatial structure and composition of bottom sediments lead to the creation of a wide range of habitats that support the development of benthic fauna. Stagnant water contributes to the sedimentation of fine-grained mineral and organic matter as well as phosphorus deposition. The value of the TOC:TN ratio increases with distance from the river because the accumulation of organic matter in bottom sediments is directly related to biomass production. Floodplain lakes are characterized by highly variable oxygen levels and qualitative parameters, such as lower nitrate concentrations (due to biosorption and denitrification) and higher ammonia and nitrite levels (due to ammonification and inhibition of nitrification) (Lefebvre et al. 2004).

Although the bottom sediments appear to be uniform, they create significant horizontal and vertical heterogeneities in the physical, chemical, and biological processes in substrata that provide a physical template for distinct niches (Hutchinson 1993). These sedimentary processes include changes in direction and rates of flows, differential deposition of sediment grain sizes and dead organisms, growth and death of roots, burrowing and sediment reworking, and fecal production by benthic consumers. Microhabitats are also created by chemical gradients and microzonation in concentrations of dissolved oxygen, hydrogen sulfide, ammonia, phosphorus, and other critical chemicals (Groffman and Bohlen 1999).

The decline in dissolved oxygen concentrations at the bottom can promote the formation of reduced compounds, such as hydrogen sulphide, resulting in higher adverse (toxic) effects on aquatic animals (Camargo and Alonso 2006). Additionally, the occurrence of toxic algae can significantly contribute to the extensive kills of aquatic animals. Cyanobacteria, dinoflagellates and diatoms appear to be major groups that may be stimulated by inorganic nitrogen pollution. Among the different inorganic nitrogenous compounds $\left(\mathrm{NH}_{4}^{+}, \mathrm{NH}_{3}, \mathrm{NO}_{2}^{-}, \mathrm{NO}_{3}^{-}\right)$that aquatic animals can take up directly from the ambient water, unionized ammonia is the most toxic, while ammonium and nitrate ions are the least toxic.

Water flow and retention time are the key factors responsible for changes in the ecosystems of restored floodplain lakes, as also demonstrated by Tockner et al. (1999). The results of our study show that restoration of full connectivity in the analyzed RFS significantly improved aeration of water, while the decreased retention time of water modified the properties of bottom sediments. The newly created habitat, which was actively flushed with river water, was not favorable for benthic macroinvertebrates. Rapid depletion of particulate organic matter with direct changes in most of the investigated parameters of bottom sediments, including conductivity (EC), total organic carbon (TOC), soluble reactive phosphorus (SRP) and total nitrogen (TN), counteracted the terrestrialization trend of the extant water body. The diversity of macrozoobenthos decreased from 19 taxa in the unaltered water bodies (plesiopotamal phase) to 5 taxa in the reconnected water bodies (eupotamal phase). 


\section{Viability of the restoration work}

The popularity of lake restoration projects is determined by their long-term effectiveness (Gore et al. 2001; Clarke et al. 2003; Sarriquet et al. 2007). The observed decrease in the nitrogen content of lake sediments may be a transitional process caused by intensified nitrification under aerobic conditions (Chapelle 1993). A periodic decrease in the organic matter content of sediments was also noted. It is difficult to predict whether lake restoration projects will induce permanent or long-lasting changes in the geochemical profile. The changes observed in the third year after the restoration of the eupotamal phase in the analyzed RFS resulted from sediment flushing, whereas in parapotamal habitats, water flow was significantly limited. Total nitrogen concentrations in river sediments increased when water exchange was partially inhibited (Table 1). The above indicates that the restoration of hydrological connectivity in the RFS contributes to the deposition and elimination of nitrogen from floodplain areas (Zalewski 2006). During inundation events in the Słupia River, water circulation in floodplain lakes is intensified, which lowers SRP concentrations due to sediment resuspension. The longer water residence time increases the sedimentation and deposition of phosphorus. Consequently, conservation measures in floodplains should involve the restoration of hydrological connectivity in the RFS and effective management of the entire catchment area.

\section{Effects of restoration on invertebrate assemblages}

Habitat conditions and their heterogeneity significantly influence invertebrate populations (Erman and Erman 1984; Merz and Ochikubo Chan 2005). River habitats are modified by changes in the abundance of aquatic macrophytes (Humphries 1996) and/or unobstructed flow of the river channel (Hall et al. 2001). Recent experiments conducted in restored floodplains have demonstrated that unconstrained movement of water from the main stream contributes to habitat heterogeneity and modifies the structure of hydrobionts (Gallardo et al. 2012; Miranda et al. 2014; Paillex et al. 2015). In the present study, a significant increase in the density and diversity of benthic macroinvertebrates was noted in restored oxbow lakes in the Słupia River floodplain over the analyzed period (Table 2). Our findings validate the observations of Ward and Stanford (1995) that floodplains provide supportive habitats for benthic macroinvertebrates. Despite these findings, the restoration of oxbow lakes in the Stupia River floodplain did not lead to a significant increase in the biological diversity of benthic fauna (Table 2). However, the restored hydrological connectivity between the floodplain lakes and river influenced the fluctuation of diversity. The restored floodplain lakes (eupotamal phase) were subjected to two contradictory influences. The inflow of water from the main stream improved water quality in the lakes with respect to oxygen concentration (Obolewski et al. 2016) but despite this it led to a decrease in diversity and abundance of benthic macroinvertebrates due to bottom sediment rinsing. According to Culp et al. (1983), the availability of organic matter is a more critical factor in explaining the composition and density of invertebrate communities than the physical properties of bottom sediments. Therefore, despite an improvement in the physicochemical parameters of the habitat, benthic fauna was influenced by the gradual decrease in organic matter content. The period during which unconstrained water flow was maintained in the oxbow lakes also influenced the abundance and diversity of benthic fauna because the hydrological status of the Słupia River floodplain contributed to a decrease in the diversity and abundance of invertebrates in the river (Table 3 ).

Changes in the physicochemical properties of sediments in the different phases of connectivity resulted in an increase in the abundance of gathering collectors-GC (Fig. 3c). During the parapotamal and plesiopotamal phases, the percentage of (GC) and filtering collectors (FC) increased. Predators (Pd) did not appear to respond to the hydrological conditions; their presence was associated with the abundance of prey, mainly of the FC guild (Fig. 5b).

Our study was conducted relatively soon after the lake restoration project; therefore, the observed changes in macroinvertebrate communities could be characteristic of the post-colonization phase (Ruhí et al. 2013). The noted processes can, however, be used to identify the main change trends and predict the success of the restoration project, whose main goal was to create stable habitats in the Słupia River floodplain. This is an important consideration because the initially eupotamal habitats were transformed into parapotamal environments, and hydrological connectivity was the main factor influencing the results of this study (Fig. 5a-c). Restricted flow inhibited hydrobiont migration. The observed increase in the abundance of benthic fauna resulted mainly from the increase in the abundance of Oligochaeta, which readily colonizes habitats with high organic matter content and effectively replace less tolerant invertebrate species (Schenková and Helešic 2006).

Changes in outflow and the shorter water retention time in restored habitats also influence the diversity of benthic fauna (Tockner et al. 1999). A decrease in the flow rate modifies habitat conditions in ecosystems and leads to changes in biogeochemical processes (Zalewski 2006) and aquatic fauna (Gallardo et al. 2012; Obolewski et al. 2016). Inhibited flow 
Fig. 3 Composition of invertebrates in relation to the hydrological connectivity phase: density of invertebrates taxa (a indiv. $\mathrm{m}^{-2}$ ), relative density of invertebrates taxa $(\mathbf{b} \%)$ and relative density of functional fedding (c \%). Sd shredders, GS grazer scrapers, $G C$ gathering collectors, $F C$ filtering collectors, $P d$ predators

\section{A} parapotamic

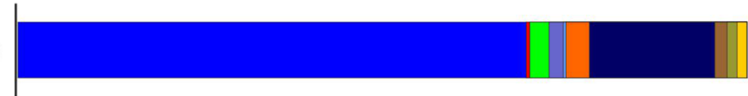

eupotamic<smiles>c1ccc(C23CC4CC(C2)C(C4)C3)cc1</smiles>

plesiopotamic

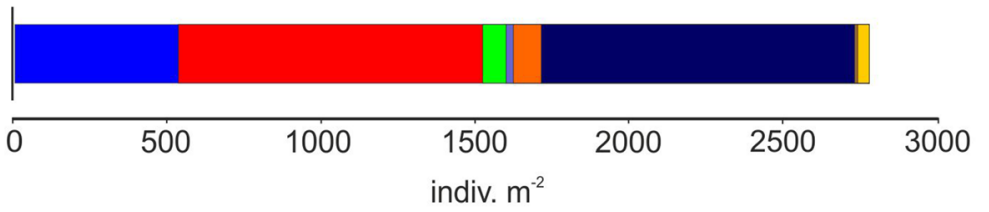

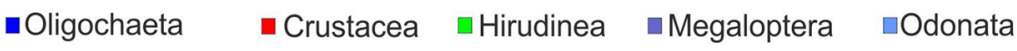

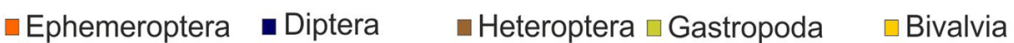

B parapotamic

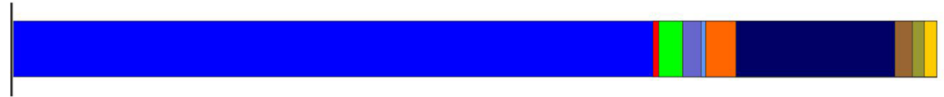

eupotamic

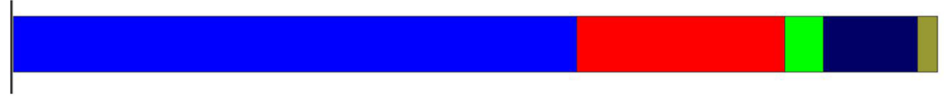

plesiopotamic

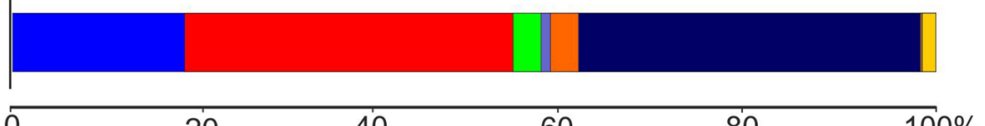

-Oligochaeta - Crustacea $\square$ Hirudinea $\backsim$ Megaloptera $₫$ Odonata

-Ephemeroptera - Diptera $\quad$ Heteroptera $\square$ Gastropoda $\square$ Bivalvia

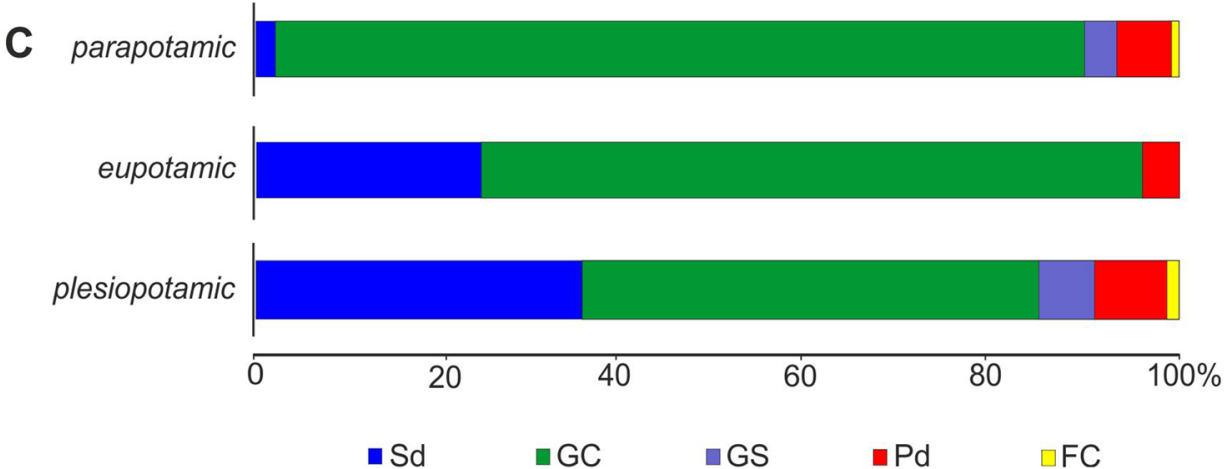

generally decreases the density and abundance of invertebrate species (Meyer and Meyer 2000; Boulton 2003) and leads to changes in the size and age structure of hydrobiont populations (Lake 2003). The results of our study indicate that floodplain ecosystems are more likely to thrive in RFS characterized by a partial parapotamal rather than parapotamal phase. Other authors have observed that the main goal of floodplain restoration projects should be to "refresh" the biotope with river water (Ward et al. 2002; Paillex et al. 2015), consistent with our findings. 
Fig. 4 Two-way cluster analysis dendrogram of 14 plots and 25 macroinvertebrate taxa. Each square represents relative abundance by column (darker is more abundant). The plot clusters are indicated at the branch tips with vertical black lines and at the node with numbers. The site clusters are indicated with red color. Codes for organism names: OLI, Oligochaeta; Ase_ aqu, Asellus aquaticus; Gam_ pul, Gammarus pulex; Glos_ com, Glossiphonia complanata; Erp_oct, Erpobdella octoculata; Hel_sp., Hellobdela sp.; Sia_ ful, Sialis fuliginosa; Les_sp., Lestes sp.; Clo_dip., Cloëon dipterum; Eph_dan, Ephemera danica; Chir_sp., Chironomus sp.; Chao_sp., Chaoborus sp.; Pol_sor, Polypedilum sordens; Ser_sp., Sergentia sp.; Pro_sp., Procladius sp.; Cor_sp., Corixa sp.; Hes_sp., Hesperocorixa sp.; Nep_cin, Nepa cinera; Cym_ sp., Cymbiodyta sp.; Sig_sp., Sigara sp.; Dyt_mar, Dytiscus marginalis; Viv_con, Viviparus contectus; Ano_ana, Anodonta anatina; Pis_sp., Pisidum sp.; Sph_sp., Sphaerium sp.
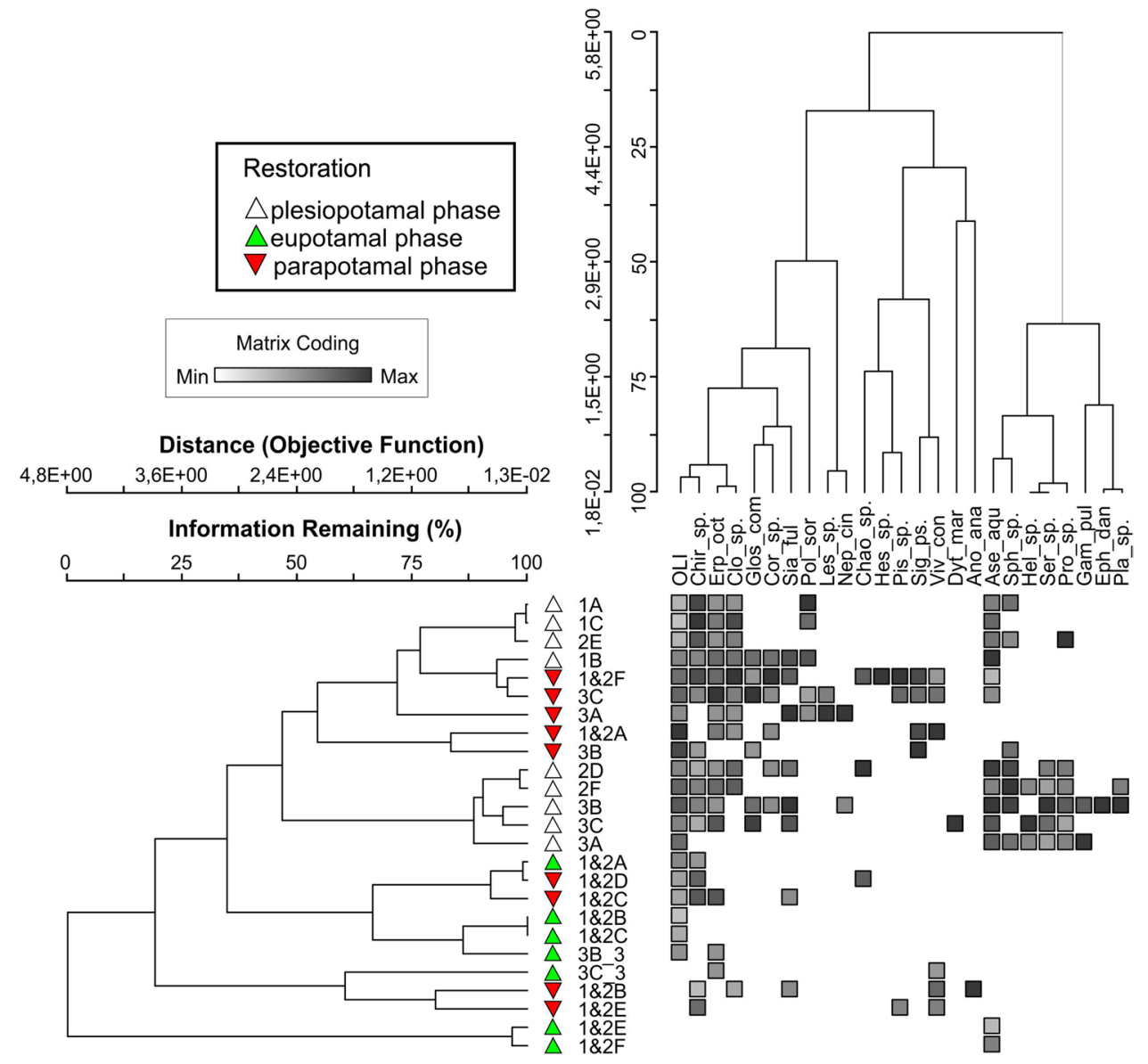
万人
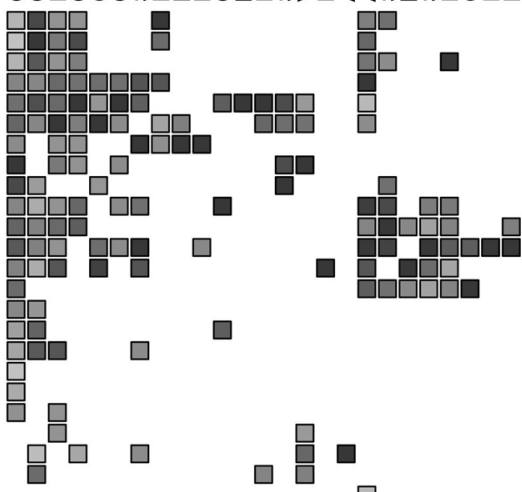

\section{Conclusions}

The results of this study validate the hypothesis that the restoration of hydrological connectivity in RFS influences the properties of bottom sediments in floodplain lakes. The conservation project also exerted a significant influence on benthic fauna, but the abundance of macroinvertebrate taxa was more correlated with hydrological connectivity than sediment properties. The gradual loss of hydrological connectivity led to significant changes in the structure and chemical composition of bottom sediments and increased the abundance and diversity of macroinvertebrates. Where possible river valleys should be allowed to flood periodically and thus naturally create one extensive ecological system. Our findings indicate that floodplain lakes should be periodically connected with their rivers to "refresh" their biotope.

Our study reveals that conservation projects aimed at restoring connectivity between floodplain areas and the main stream are unable to prevent natural erosion and accumulation processes or alter the dynamics of a river's hydrological regime. Restoration projects should be developed in view of long-term natural hydrodynamic processes, which determine the success of conservation measures. This study documents the ecological consequences of a restoration project over a period of only 5 years, but the geochemical profile of the floodplain could undergo significant changes in the long term. Such changes are influenced by the inflow of dissolved substances from the catchment and other physical factors (inundation, erosion of the river bed). Therefore, to ensure maximum sustainability, projects that restore hydrological connectivity in a floodplain should also involve effective management of catchment areas, including limited fertilizer use, creation of buffer zones and protection of littoral vegetation. 
Fig. 5 The triplot of redudency analysis (a) for the environmental variables, samples and composition of benthofauna and biplot for the environmental variables and functional feeding groups (b). Codes for organism names the same as for Fig. 4.

General linear model (c) for the environmental variables and distribution of $\mathrm{D} \alpha$

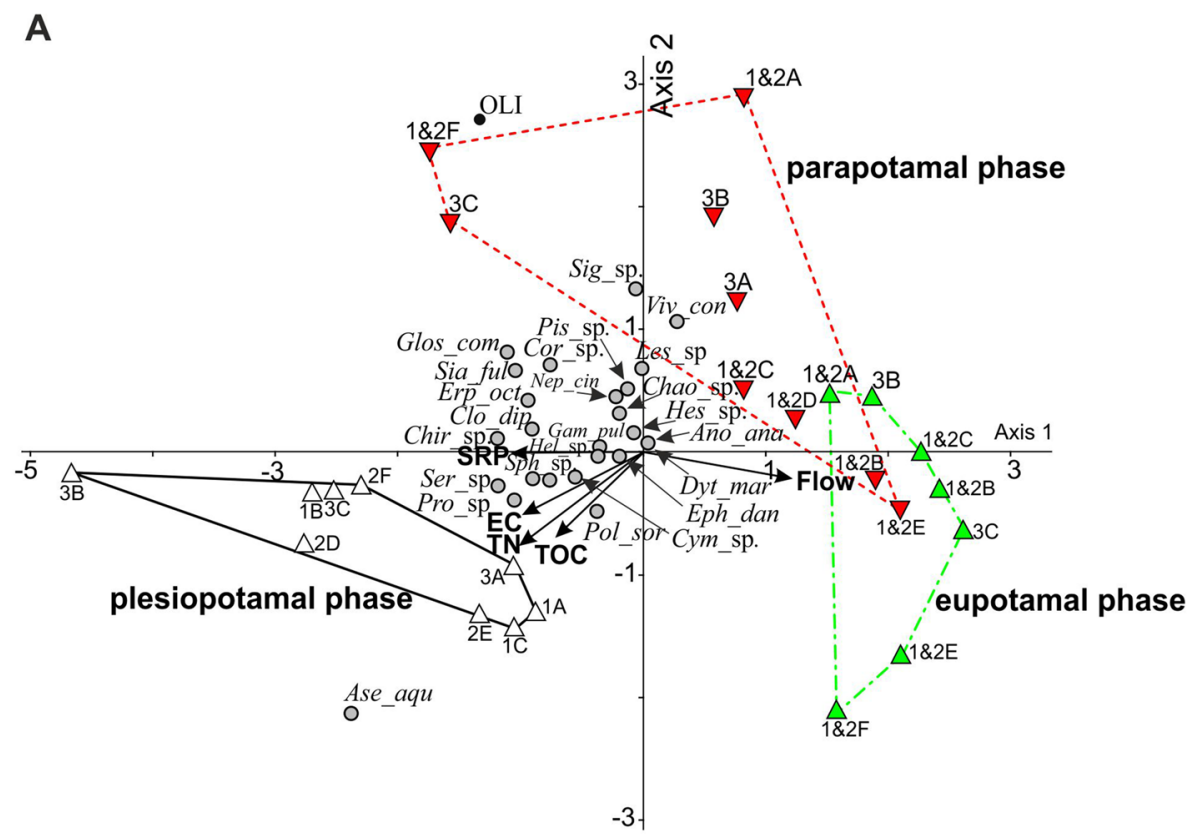

B

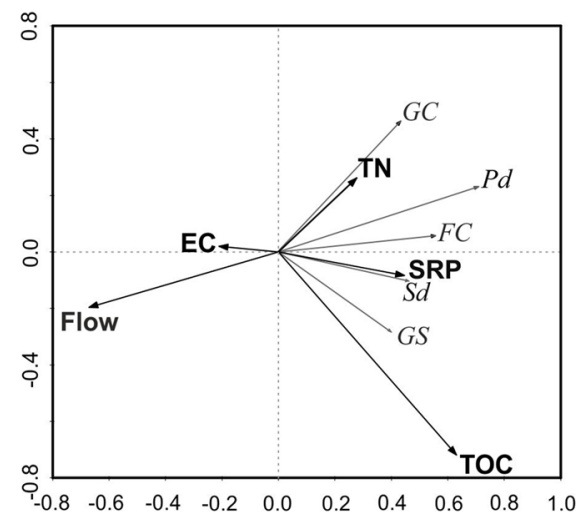

C

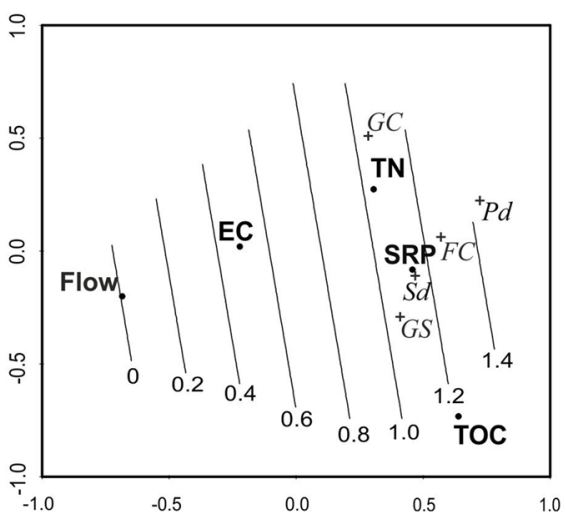

\section{Compliance with ethical standards}

Conflict of interest The authors have declared no conflict of interest.

Open Access This article is distributed under the terms of the Creative Commons Attribution 4.0 International License (http://creativecommons.org/licenses/by/4.0/), which permits unrestricted use, distribution, and reproduction in any medium, provided you give appropriate credit to the original author(s) and the source, provide a link to the Creative Commons license, and indicate if changes were made.

\section{Appendix}

See Table 4. 
Table 4 Relative density (\%) of benthofauna inhabiting the studied oxbow lakes and Słupia River before (plesiopotamic phase) and after restoration (eupotamic and parapotamic phases)

\begin{tabular}{|c|c|c|c|c|c|c|c|c|c|c|c|}
\hline & \multirow[t]{3}{*}{ FFG } & \multicolumn{7}{|c|}{ Connectivity phase } & \multirow{3}{*}{$\begin{array}{l}2007 \\
\text { River }\end{array}$} & \multirow{3}{*}{$\begin{array}{l}2011 \\
\text { upia }\end{array}$} & \multirow[t]{3}{*}{2014} \\
\hline & & \multicolumn{3}{|c|}{ Plesiopotamic } & \multicolumn{2}{|l|}{ Eupotamic } & \multicolumn{2}{|c|}{ Parapotamic } & & & \\
\hline & & OLS1 & OLS2 & OLS3 & OLS1\&2 & OLS3 & OLS1\&2 & OLS3 & & & \\
\hline Oligochaeta & $\mathrm{GC}$ & 3.0 & 23.1 & 35.7 & 55.7 & 76.9 & 66.3 & 79.6 & 4.7 & 3.2 & 6.7 \\
\hline Asellus aquaticus & $\mathrm{Sd}$ & 28.4 & 35.8 & 42.9 & 30.4 & 0.0 & 0.1 & 1.4 & 4.7 & 3.2 & 0.0 \\
\hline Gammarus pulex & $\mathrm{Sd}$ & 0.0 & 0.0 & 0.5 & 0.0 & 0.0 & 0.0 & 0.0 & 0.0 & 3.2 & 0.0 \\
\hline Glossiphonia complanata & $\mathrm{Pd}$ & 0.4 & 0.0 & 2.3 & 0.0 & 0.0 & 0.1 & 3.2 & 0.0 & 0.0 & 0.0 \\
\hline Erpobdella octoculata & $\mathrm{Pd}$ & 0.8 & 1.2 & 1.0 & 0.0 & 15.4 & 1.0 & 2.8 & 2.3 & 0.0 & 0.0 \\
\hline Hellobdela sp. & $\mathrm{Pd}$ & 0.0 & 0.2 & 2.3 & 0.0 & 0.0 & 0.0 & 0.0 & 0.0 & 0.0 & 0.0 \\
\hline Sialis fuliginosa & $\mathrm{Pd}$ & 0.6 & 0.5 & 2.1 & 0.0 & 0.0 & 0.5 & 1.9 & 0.0 & 0.0 & 0.0 \\
\hline Libellula quadrimaculata & $\mathrm{Pd}$ & 0.0 & 0.0 & 0.0 & 0.0 & 0.0 & 0.0 & 0.0 & 2.3 & 6.5 & 6.7 \\
\hline Lestes sp. & $\mathrm{Pd}$ & 0.0 & 0.0 & 0.0 & 0.0 & 0.0 & 0.0 & 1.4 & 0.0 & 3.2 & 0.0 \\
\hline Cloëon dipterum & GS & 4.0 & 5.5 & 0.0 & 0.0 & 0.0 & 4.1 & 1.4 & 0.0 & 22.6 & 6.7 \\
\hline Ephemera danica & GS & 0.0 & 0.0 & 0.3 & 0.0 & 0.0 & 0.0 & 0.0 & 16.3 & 0.0 & 0.0 \\
\hline Chironomus sp. & GC & 55.5 & 19.0 & 2.4 & 13.9 & 0.0 & 23.2 & 3.2 & 25.6 & 16.1 & 33.3 \\
\hline Chaoborus sp. & $\mathrm{Pd}$ & 0.0 & 0.5 & 0.0 & 0.0 & 0.0 & 0.2 & 0.0 & 0.0 & 0.0 & 0.0 \\
\hline Polypedilum sordens & GS & 6.8 & 0.0 & 0.0 & 0.0 & 0.0 & 0.0 & 0.7 & 7.0 & 0.0 & 0.0 \\
\hline Procladius sp. & $\mathrm{Pd}$ & 0.0 & 9.4 & 2.4 & 0.0 & 0.0 & 0.0 & 0.0 & 23.3 & 0.0 & 0.0 \\
\hline Sergentia sp. & $\mathrm{GC}$ & 0.0 & 1.0 & 5.2 & 0.0 & 0.0 & 0.0 & 0.0 & 0.0 & 0.0 & 0.0 \\
\hline Corixa sp. & $\mathrm{Pd}$ & 0.3 & 0.2 & 0.2 & 0.0 & 0.0 & 0.9 & 0.2 & 0.0 & 0.0 & 0.0 \\
\hline Hesperocorixa sp. & $\mathrm{Pd}$ & 0.0 & 0.0 & 0.0 & 0.0 & 0.0 & 0.1 & 0.0 & 0.0 & 0.0 & 0.0 \\
\hline Nepa cinera & $\mathrm{Pd}$ & 0.0 & 0.0 & 0.2 & 0.0 & 0.0 & 0.0 & 1.6 & 0.0 & 0.0 & 0.0 \\
\hline Sigara sp. & $\mathrm{Pd}$ & 0.0 & 0.0 & 0.0 & 0.0 & 0.0 & 0.4 & 0.9 & 0.0 & 0.0 & 0.0 \\
\hline Cymbiodyta sp. & $\mathrm{Pd}$ & 0.0 & 0.2 & 0.9 & 0.0 & 0.0 & 0.0 & 0.0 & 0.0 & 0.0 & 0.0 \\
\hline Dytiscus marginalis & $\mathrm{Pd}$ & 0.0 & 0.0 & 0.2 & 0.0 & 0.0 & 0.0 & 0.0 & 0.0 & 0.0 & 0.0 \\
\hline Viviaparus contectus & $\mathrm{Sd}$ & 0.0 & 0.0 & 0.0 & 0.0 & 7.7 & 2.2 & 0.7 & 2.3 & 0.0 & 0.0 \\
\hline Anodonta anatina & $\mathrm{FC}$ & 0.0 & 0.0 & 0.0 & 0.0 & 0.0 & 0.1 & 0.0 & 0.0 & 9.7 & 0.0 \\
\hline Pisidium sp. & $\mathrm{FC}$ & 0.0 & 0.0 & 0.0 & 0.0 & 0.0 & 0.7 & 0.5 & 0.0 & 16.1 & 26.7 \\
\hline Sphaerium sp. & $\mathrm{FC}$ & 0.3 & 3.4 & 1.4 & 0.0 & 0.0 & 0.0 & 0.5 & 11.6 & 16.1 & 20.0 \\
\hline
\end{tabular}

$F F G$ functional feeding group (Acronyms: $S d$ shredders, $G S$ grazer scrapers, $G C$ gathering collectors, $F C$ filtering collectors, $P d$ predators)

\section{References}

Amoros C, Bornette G (2002) Connectivity and biocomplexity in waterbodies of riverine floodplains. Freshw Biol 47:761-776

Amoros C, Roux AL (1988) Interactions between water bodies within floodplains of large rivers: function and development of connectivity. Munst Geogr Arb 29:125-130

ter Braak CJF (1995) Ordination. In: Jongman RHG, ter Braak CJF, van Tongeren OFR (eds) Data analysis in community and landscape ecology. Cambridge University Press, England, pp 91-173

ter Braak CJF, Smilauer P (2002) CANOCO reference manual and CanoDraw for Windows User's Guide: software for canonical community ordination (version 4.5). Microcomputer Power, Ithaca

Boulton AJ (2003) Parallels and contrasts in the effects of drought on stream invertebrate assemblages. Freshw Biol 48:1173-1185

Buijse T, Klijn F, Leuven RSEW., Middlekoop H, Schiemer F, Thorp JH, Wolfert HP (2005) Rehabilitation of large rivers: references, achievements. Arch Hydrobiol 155:715-720
Camargo JA, Alonso Á (2006) Ecological and toxicological effects of inorganic nitrogen pollution in aquatic ecosystems: a global assessment. Environ Int 32:831-849. https://doi.org/10.1016/j. envint.2006.05.002

Chapelle FH (1993) Groundwater microbiology and geochemistry. J Wile, New York

Clarke SJ, Bruce-Burgess L, Wharton G (2003) Linking form and function: towards an eco-hydromorphic approach to sustainable river restoration. Aquat Conserv 13:439-450. https://doi.org/10.1002/ aqc. 591

Covich AP, Palmer MA, Crowl TA (1999) The role of benthic invertebrate species in freshwater ecosystems. Bioscience 49:119-127. https://doi.org/10.2307/1313537

Crawley MJ (2007) Generalized linear models. In: The R book, Wiley, Chichester. https://doi.org/10.1002/9780470515075.ch13

Culp JM, Walde SJ, Davies RW (1983) Relative importance of substrate particle size and detritus to stream benthic macroinvertebrate microdistribution. Can J Fish Aquat Sci 40:568-1574. https://doi.org/10.1139/f83-181 
Dolédec S, Castella E, Forcellini M, Olivier JM, Paillex A, Sagnes $P$ (2015) The generality of changes in the trait composition of fish and invertebrate communities after flow restoration in a large river (French Rhône). Freshw Biol 60:1147-1161. https://doi. org/10.1111/fwb.12557

Erman DC, Erman NA (1984) The response of stream macroinvertebrates to substrate size and heterogeneity. Hydrobiologia 108:7582. https://doi.org/10.1007/BF00028185

Gallardo B, Cabezas A, González E, Comin FA (2012) Effectiveness of a newly created oxbow lake to mitigate habitat loss and increase biodiversity in a regulated floodplain. Restor Ecol 20:387-394. https://doi.org/10.1111/j.1526-100X.2010.00766.x

Gallardo B, Dolédec S, Paillex A, Arscott DB, Sheldon F, Zilli F, Mérigoux S, Castella E, Comín FA (2014) Response of benthic macroinvertebrates to gradients in hydrological connectivity: a comparison of temperate, subtropical, Mediterranean and semiarid river floodplains. Freshw Biol 59:630-648. https://doi. org/10.1111/fwb. 12292

Gore JA, Layzer JB, Mead J (2001) Macroinvertebrates instream flow studies after 20 years: a role of instream management and restoration. Regul Rivers 17:527-542. https://doi.org/10.1002/rrr.650

Groffman PM, Bohlen PJ (1999) Soil and sediment biodiversity. Bioscience 49:139-148

Hall MJ, Closs GP, Riley RH (2001) Relationships between land use and stream invertebrate community structure in a South Island, New Zealand, coastal stream catchment. New Zeal J Mar Freshw 35:591-603. https://doi.org/10.1080/00288330.2001.9517025

Humphries P (1996) Aquatic macrophytes, macroinvertebrate associations and water levels in a lowland Tasmanian river. Hydrobiologia 321:219-233. https://doi.org/10.1007/BF00143752

Hutchinson GE (1993) A Treatise on limnology. The zoobenthos. Wiley, New York

Jones SE, Jago CF (1992) In situ assessment of modification of sediment properties by burrowing invertebrates. Mar Biol 115:133142. https://doi.org/10.1007/BF00349395

Junk WJ, Bayley PB, Sparks RE (1989) The flood pulse concept in river-floodplain systems. In: Dodge DP (ed). Proceedings of the international large river symposium, pp 110-121

Lake PS (2003) Ecological effects of perturbation by drought in flowing waters. Freshw Biol 48:1161-1172. https://doi. org/10.1046/j.1365-2427.2003.01086.x

Lefebvre S, Marmonier P, Pinay G (2004) Stream regulation and nitrogen dynamics in sediment interstices: comparison of natural and straightened sectors of a third order stream. River Res Appl 20:499-512. https://doi.org/10.1002/rra.765

Legendre P, Legendre L (2012) Numerical ecology. 3rd edn. Elsevier, Amsterdam

McCune B, Mefford MJ (2011) PC-ORD, multivariate analysis of ecological data. Version 6.0. MjM Software Design, Gleneden Beach

Merritt RW, Cummins KW (2007) Trophic relationships of macroinvertebrates. In: Hauer FR, Lamberti GA (eds) Methods in stream ecology. Elsevier, New York, pp 585-610

Merz JE, Ochikubo Chan LK (2005) Effects of gravel augmentation on macroinvertebrate assemblages in a regulated California river. River Res Appl 21:61-74. https://doi.org/10.1002/rra.819

Mesa LM, Marchese MR, Montalto L, Zilli FL (2012) Bidirectional exchanges of benthic invertebrates in a large river-floodplain system (Paraná River, Argentina). Ann Limnol Int J Lim 48:425-436. https://doi.org/10.1051/limn/2012030

Meyer A, Meyer EI (2000) Discharge regime and the effect of drying on macroinvertebrate communities in a temporary karst stream in east Westphalia (Germany). Aquat Sci 62:216-231. https://doi. org/10.1007/PL00001333

Meyers PA (2003) Applications of organic geochemistry to paleolimnological reconstructions: a summary of examples from the
Laurentian Great Lakes. Org Geochem 34:261-289. https://doi. org/10.1016/S0146-6380(02)00168-7

Miranda LE, Andrews CS, Kröger R (2014) Connectedness of land use, nutrients, primary production, and fish assemblages in oxbow lakes. Aquat Sci 76:41-50. https://doi.org/10.1007/ s00027-013-0310-y

Murphy J, Riley JP (1962) A modified single solution method for the determination of phosphate in natural waters. Anal Chim Acta 27:31-36

Obolewski K (2011) Composition and density of plant-associated invertebrates in relation to environmental gradients and hydrological connectivity of wetlands. Oceanol Hydrobiol Stud 40:52-63. https://doi.org/10.2478/s13545-011-0041-4

Obolewski K, Glińska-Lewczuk K (2013) Distribution of heavy metals in bottom sediments of floodplain lakes and their parent river-a casy study of the Słupia River. J Elementol 18:673-682. https:// doi.org/10.5601/jelem.2013.18.4.435

Obolewski K, Glińska-Lewczuk K, Ożgo M, Astel A (2016) Connectivity restoration of floodplain lakes: an assessment based on macroinvertebrate communities. Hydrobiologia 774:23-37. https://doi.org/10.1007/s10750-015-2530-8

Paillex A, Castella E, zu Ermgassen PSE, Aldridge DC (2015) Testing predictions of changes in alien and native macroinvertebrate communities and their interaction after the restoration of a large river floodplain (French Rhône). Freshw Biol 60:1162-1175. https:// doi.org/10.1111/fwb.12541

Palmer MA, Bernhardt ES, Allan JD, Lake PS, Alexander G, Brooks S, Carr J, Clayton S, Dahm C, Follstad Shah J, Galat DJ, Gloss S, Goodwin P, Hart DH, Hassett B, Jenkinson R, Kondolf GM, Lave R, Meyer JL, O’Donnell TK, Pagano L, Srivastava P, Sudduth E (2005) Standards for ecologically successful river restoration. J Appl Ecol 42:208-217. https://doi. org/10.1111/j.1365-2664.2005.01004.x

Reckendorfer W (2004) Effects of the hydrological connectivity between the main channel and it's floodplain on benthic invertebrates. Abhandlungen der Zoologisch-Botanischen Gesellschaft in Österreich 34:77-98

Rempel LL, Richardson JS, Healey MC (2000) Macroinvertebrate community structure along gradients of hydraulic and sedimentary conditions in large gravel-bed river. Freshw Biol 45:57-73. https://doi.org/10.1046/j.1365-2427.2000.00617.x

Ruhí A, Boix D, Gascón S, Sala J, Batze DP (2013) Functional and phylogenetic relatedness in temporary wetland invertebrates: current macroecological patterns and implications for future climatic change scenarios. PLoS One 8:e81739. https://doi.org/10.1371/ journal.pone.0081739

Sarriquet PE, Bordenave P, Marmonier P (2007) Effects of bottom sediment restoration on interstitial habitat characteristics and benthic macroinvertebrate assemblages in a headwater stream. River Res Appl 23:815-828. https://doi.org/10.1002/rra.1013

Sartori L, Sergio S, Cabrini R, Fornaroli R, Mezzanotte V (2015) Macroinvertebrate assemblages and biodiversity levels: ecological role of constructed wetlands and artificial ponds in a natural park. $\mathrm{J}$ Limnol 74:335-345. https://doi.org/10.4081/jlimnol.2014.1018

Schenková J, Helešic J (2006) Habitat preferences of aquatic Oligochaeta (Annelida) in the Rokytná River, Czech Republic- a small highland stream. Hydrobiologia 564:117-126. https://doi. org/10.1007/s10750-005-1713-0

Schiemer F, Baumgartner C, Tockner K (1999) Restoration of floodplain rivers: The 'Danube restoration project'. River Res Appl 15:231-244. https://doi.org/10.1002/(SICI)10991646(199901/06)15:1/3<231:AID-RRR548>3.0.CO;2-5

Sieczko A, Peduzzi P (2014) Origin, enzymatic response and fate of dissolved organic matter during flood and non-flood conditions in a river-floodplain system of the Danube (Austria). Aquat Sci 76:115-129. https://doi.org/10.1007/s00027-013-0318-3 
Svensson JM, Leonardson L (1996) Effects of bioturbation by tubedwelling chironomids larvae on oxygen uptake and denitrification in eutrophic lake sediments. Freshw Biol 35:289-300. https://doi. org/10.1046/j.1365-2427.1996.00500.x

Technicon Industrial Systems (1973) Orthophosphate in water and seawater. Autoanalyzer IIR Industrial Method No. 155-71W. W. Tarrytown, New York, p 10591

Tockner K, Pennetzdorfer D, Reiner N, Schiemer F, Ward JV (1999) Hydrological connectivity, and the exchange of organic matter and nutrients in a dynamic river-floodplain system (Danube, Austria). Freshw Biol 41:521-535. https://doi. org/10.1046/j.1365-2427.1999.00399.x

Ward JV, Stanford JA (1995) Ecological connectivity in alluvial river ecosystems and its disruption by flow regulation. Regul Rivers 11:105-119. https://doi.org/10.1002/rrr.3450110109
Ward JV, Tockner K, Arscott DB, Claret C (2002) Riverine landscape diversity. Freshw Biol 47:517-539. https://doi. org/10.1046/j.1365-2427.2002.00893.x

Willacker JJJ, Sobczak WV, Colburn EA (2009) Stream macroinvertebrate communities in paired Hemlock and Deciduous watersheds. Northeast Nat 16(1):101-112

Zalewski M (2006) Ecohydrology—an interdisciplinary tool for integrated protection and management of water bodies. Arch Hydrobiol 158/4:613-622. https://doi.org/10.1127//r/16/2006/613

Żbikowski J, Kobak J (2007) Factors influencing taxonomic composition and abundance of macrozoobenthos in extralittoral zone of shallow eutrophic lakes. Hydrobiologia 584:145-155. https://doi. org/10.1007/s10750-007-0613-x 